\title{
U.S. Pellet Industry Analysis
}

Jake Jacobson

Corrie Nichol

Richard D. Boardman

June 2011

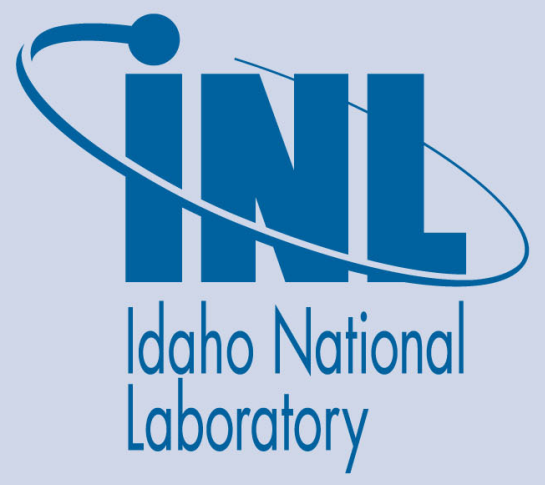

The INL is a U.S. Department of Energy National Laboratory operated by Battelle Energy Alliance 
INL/EXT-11-21811

\title{
U.S. Pellet Industry Analysis
}

\author{
Jake Jacobson \\ Corrie Nichol \\ Richard D. Boardman
}

June 2011

\begin{abstract}
Idaho National Laboratory
Idaho Falls, Idaho 83415
\end{abstract}

http://www.inl.gov

Prepared for the

U.S. Department of Energy

Under DOE Idaho Operations Office

Contract DE-AC07-05ID14517 
INL/EXT-11-21811

\title{
US Pellet Industry Analysis
}

\author{
Authors: Jake Jacobson, Corrie Nichol, Richard D. Boardman
}

\author{
June 2011
}

\section{Introduction}

This report is a survey of the U.S. Pellet Industry, its current capacity, economic drivers, and projected demand for biomass pellets to meet future energy consumption needs.

Energy consumption in the United States is projected to require an ever increasing portion of renewable energy sources including biofuels, among which are wood, and agricultural biomass [1] (see Figure 1). Goals set by federal agencies will drive an ever increasing demand for biomass.

The EIA projections estimate that renewable energy produced by 2035 will be roughly $10 \%$ of all U.S. energy consumption. Further analysis of the biofuels consumption in the U.S. shows that of the renewable energy sources excluding biofuels, nearly $30 \%$ are wood or biomass waste (see Figure 4 ). This equates to roughly $2 \%$ of the total energy consumption in the U.S. coming from biomass in 2009 , and the projections for 2035 show a strong increase in this amount. As of 2009, biomass energy production equates to roughly 2-2.5 quadrillion Btu.

The EIA projections also show coal as providing $21 \%$ of energy consumed. If biomass is blended at $20 \%$ to co-fire coal plants, this will result in an additional 4 quadrillion Btu of biomass consumption [1].

The EISA goals aim to produce 16 billion gal/year of cellulosic biofuels [2], and the U.S. military has set goals for biofuels production. The Air Force has proposed to replace $50 \%$ of its domestic fuel requirements with alternative fuels from renewable sources by 2016. The Navy has likewise set a goal to provide $50 \%$ of its energy requirements from alternative sources [3].

The Department of Energy has set similarly ambitious goals [4]. The DOE goal is to replace $40 \%$ of 2004 gasoline use with biofuels. This equates to roughly 60 billion gal/year, of which, 45 billion gal/year would be produced from lignocellulosic resources. This would require 530 million dry tons of herbaceous and woody lignocellulosic biomass per year.

A study conducted by Oak Ridge National Laboratory [5] estimates the total available biomass in the U.S., including crop residue, purpose grown energy crops, and forest resources at over one billion dry tons annual production capacity. A similar study by the National Academy of Sciences estimates a total of 416 million tons [6]. If a conservative estimate of possible biomass sources were taken to be roughly 700 million dry tons, this would result in a potential energy production of 12.75 quadrillion Btu.

In order to fill the increasing reliance on biomass for energy use, biomass must be economically transportable, and uniform in its properties. The Feedstock Logistics Interagency Working Group of the Biomass Research and Development Board recommended in their 2011 report [7], among other things, 
that systems are required to increase feedstock bulk density. This is required in order to make biomass for energy production economically viable. If biomass is to be transported more than 200 miles from the point of collection to the point of end use, it will only be economically viable if the bulk density of the biomass is sufficiently high. Pelleting biomass is a primary technology currently in use for increasing biomass bulk density, and enables economic long distance transportation of biomass for energy production. Pelleting also provides a means of ensuring uniformity in biomass properties delivered to the end user. It enables a variety of feedstock materials, in a variety of raw forms to be made uniform and standardized, resulting in the necessary commodity market for biomass utilization.

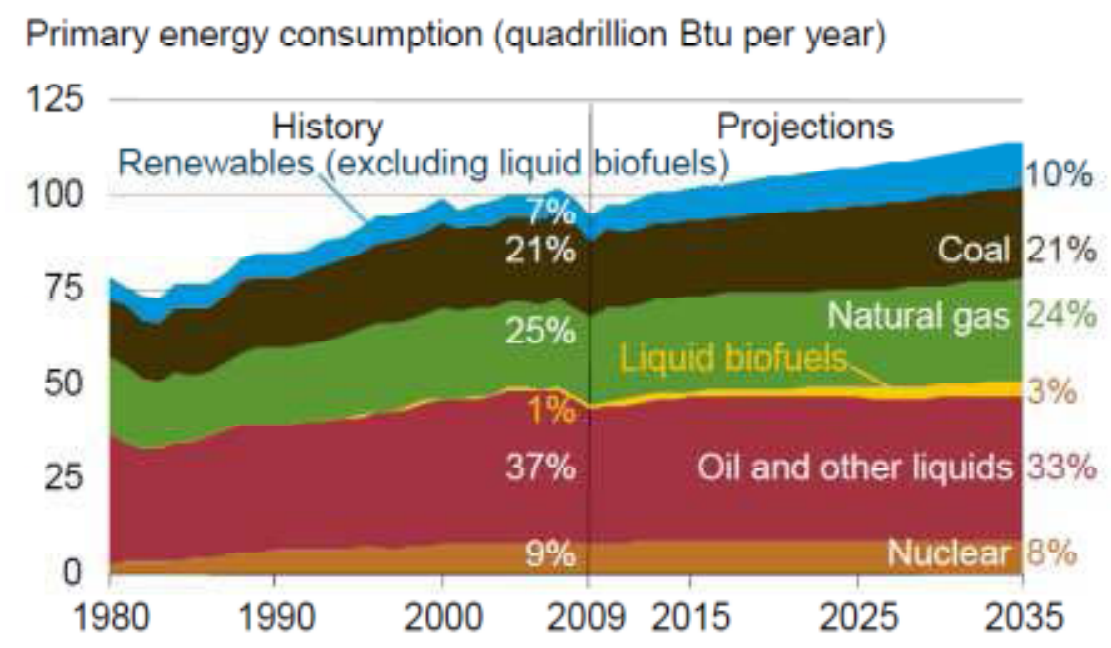

Figure 1: Primary Energy Consumption by Fuel (Source: [1])

This report considers the consumption and export of pellets in the U.S., raw material availability in the U.S., the current pellet production and capacity, including proposed pellet plants. It also considers end use of pellets produced in the U.S., energy prices and economic drivers for use of biomass pellets, and some future projections for the U.S. pellet industry.

\section{Raw Material}

There are many under-utilized sources of biomass in the U.S. that could be collected, pelleted, and used for energy production. The predominant source currently used for pellets in the U.S. is sawmill residue, the second being chips and roundwood depending on the capacity of different plants. Primary mill residue in the nation yielded 77.125 million dry tonnes/year (85.016 million tons/year). Of that total, 1.606 million tonnes (1.770 million tons) went unused (see Table 1), and were burned as waste or disposed of in landfills [8].

An analysis of available crop residue in the United States, excluding residue necessary for soil health, grazing, and other uses, and based on total grain production shows over 157 million tonnes of residue that could be collected [8].

Table 1: Estimated Primary Mill Residues by State (Thousand Dry Tonnes) (Source: [8])

\begin{tabular}{|l|r|r||l|r|r|}
\hline State & Total & Unused & State & Total & Unused \\
\hline Alabama & 5,857 & 10 & Montana & 1,937 & 41 \\
\hline Alaska & 231 & 131 & Nebraska & 57 & 9 \\
\hline
\end{tabular}




\begin{tabular}{|l|r|r||l|r|r|}
\hline State & Total & Unused & State & Total & Unused \\
\hline Arizona & 109 & 0.2 & Nevada & 0 & 0 \\
\hline Arkansas & 3,623 & 2 & New Hampshire & 925 & 19 \\
\hline California & 4,772 & 8 & New Jersey & 17 & 0.2 \\
\hline Colorado & 181 & 87 & New Mexico & 165 & 4 \\
\hline Connecticut & 75 & 0 & New York & 1,063 & 24 \\
\hline Delaware & 14 & 0.05 & North Carolina & 3,900 & 14 \\
\hline District of Columbia & 0 & 0 & North Dakota & 0 & 0.2 \\
\hline Florida & 1,901 & 4 & Ohio & 786 & 18 \\
\hline Georgia & 7,231 & 66 & Oklahoma & 633 & 0 \\
\hline Hawaii & 0 & 0 & Oregon & 6,454 & 9 \\
\hline Idaho & 4,400 & 69 & Pennsylvania & 1,358 & 144 \\
\hline Illinois & 233 & 14 & Rhode Island & 21 & 0 \\
\hline Indiana & 574 & 26 & South Carolina & 2,468 & 9 \\
\hline Iowa & 130 & 2 & South Dakota & 142 & 5 \\
\hline Kansas & 29 & 5 & Tennessee & 1,557 & 153 \\
\hline Kentucky & 1,433 & 77 & Texas & 2,085 & 8 \\
\hline Louisiana & 3,577 & 14 & Utah & 102 & 20 \\
\hline Maine & 421 & 35 & Vermont & 103 & 0 \\
\hline Maryland & 138 & 0.2 & Virginia & 2,147 & 66 \\
\hline Massachusetts & 113 & 0 & Washington & 5,597 & 6 \\
\hline Michigan & 1,314 & 41 & West Virginia & 807 & 114 \\
\hline Minnesota & 985 & 65 & Wisconsin & 1,621 & 30 \\
\hline Mississippi & 4,548 & 79 & Wyoming & 255 & 47 \\
\hline Missouri & 1,036 & 130 & U.S. Total & $\mathbf{7 7 , 1 2 5}$ & $\mathbf{1 , 6 0 6}$ \\
\hline
\end{tabular}

Further analysis of available production potential in the U.S. estimates the total potential biomass production is just over 1.3 billion dry tons [5].

In a similar study, the National Academy of Sciences estimated that the total current production capacity is 414 million tons annually, with a projected increase to 548 million tons/year by 2020 . This study included agricultural residue, dedicated fuel crops, woody residue, animal manure, and municipal solid waste [6].

In order to capitalize on the available resources discussed above, a means must be adopted to standardize and commoditize biomass for the market. If biomass is to be transported economically more than 200 miles, it must be made more dense and durable. Pelleting is a leading technology for accomplishing this objective, by providing a higher bulk density, uniform format for utilization in energy production, and more durable long-term storage properties.

\section{Production and Capacity}

A small pellet industry came into existence in the 1930s. Its main growth began in the wake of the energy crisis in the 1970s, with an even greater acceleration of growth in the past decade, driven largely by renewable energy standards. In 2003, for example, world-wide production stood at roughly 1.1 million tonnes, which increased to 4.2 million tonnes in 2008 [9]. As of 2010, the total production capacity has again increased to just under 6 million dry tonnes, with much of the recently added capacity intended for shipment to Europe.

Most plants in the U.S. in 2009 were small, relying on sawmill residue outputs for fiber and thus were typically limited to 100,000 tonnes or less per year [9]. 
Table 2: U.S. Estimated Wood Pellet Production Capacity by Sector (Source: [9])

\begin{tabular}{|l|r|r|r|r|r|r|r|}
\hline $\begin{array}{l}\text { Estimated Capacity by } \\
\text { Year }\end{array}$ & $\mathbf{2 0 0 3}$ & $\mathbf{2 0 0 4}$ & $\mathbf{2 0 0 5}$ & $\mathbf{2 0 0 6}$ & $\mathbf{2 0 0 7}$ & $\mathbf{2 0 0 8}$ & $\mathbf{2 0 0 9}$ \\
\hline U.S. Northeast & 140 & 143 & 180 & 253 & 416 & 589 & 1056 \\
\hline U.S. West & 281 & 308 & 354 & 458 & 473 & 589 & 711 \\
\hline U.S. North & 122 & 122 & 158 & 344 & 502 & 964 & 1855 \\
\hline U.S. South & 12 & 25 & 59 & 183 & 357 & 424 & 702 \\
\hline Total & $\mathbf{5 5 5}$ & $\mathbf{5 9 8}$ & $\mathbf{7 5 1}$ & $\mathbf{1 2 3 8}$ & $\mathbf{1 7 4 8}$ & $\mathbf{2 5 6 6}$ & $\mathbf{4 3 2 4}$ \\
\hline & Capacity $\left(* 10^{3}\right.$ tonnes $)$ & & & & & \\
\end{tabular}

The reliance on sawmill residues led to imbalances between supply and demand for biomass as the sawmilling sector retrenched in the 2008-2009 recession. This led pellet mills to turn to roundwood or other non-sawmill sources of biomass. In 2008, wood pellet production in the United States massed 1.8 million tonnes, just 66 percent of capacity as a result of limited mill residue availability which constrained plant activity output [9].

A number of new mills have been built recently to process chipped roundwood. Their independence from the sawmill industry has allowed a focus on export of wood pellets, and some of the newer plants have capacities of 300,000-400,000 tonnes/year [9]. In 2009 the U.S. pellet industry was projected to have a total capacity of over 4.3 million tonnes (see Table 2 \& Figure 2), and recent additions have brought total capacity to around 6 million tonnes. The wood pellet industry and use of wood pellets as energy are in their relative infancy in North America and the recent growth of both has been fueled by increases in the cost of fossil energy as well as government policies that will continue to shape the renewable energy market. Policies aimed at reducing carbon dioxide emissions loom as bigger factors to rising pellet production in the future [9].

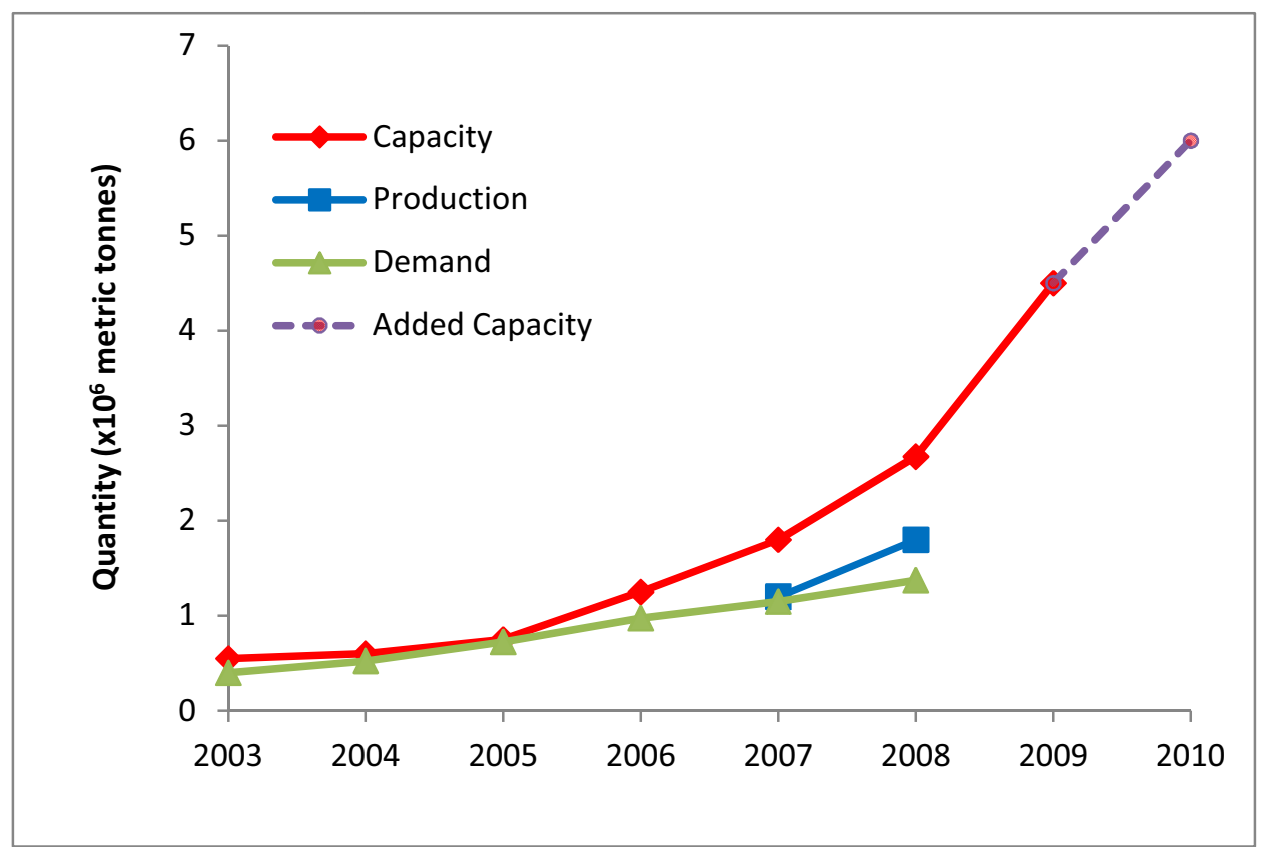

Figure 2: Capacity, Production and Demand for Wood Pellets in the U.S. (Source: [9] with added data) 
In the New England States, for example, continually rising oil prices are responsible for the growth of pellets sales as private home owners look for more economical ways to heat their homes. It is expected that production will grow by 890,000 tons for the 2010/2011 heating season [9].

\section{Proposed Pellet Plants}

As stated above, the US pellet industry has grown rapidly in the past few years, and will continue to expand. More construction and new plants, or expansions will be built to support the push for an increase in renewable energy production. Figure 3 below shows the location and relative size of pellet producers in the United States.

The majority of pellet mills in the US are small scale in comparison to the pulp and paper or power industry. The average pellet mill in the US has a capacity of between 30,000-70,000 tonnes. Pellet plants are generally constrained due to a business model based on utilization of a waste product and residue provided by sawmills. However, in the U.S. southern region some mills are moving to roundwood for their supply and these mills feature some of the largest mills in the U.S. Green Circle Bio Energy's 560,000 ton/year capacity plant, for example, is the largest wood pellet plant in the world. Its production is targeted mainly for export to the European Union [10].

Magnolia Bio Power, in Georgia also has plans for a plant that, when fully operational, will reach 900,000 tons of torrefied wood pellets annually and produce $30 \mathrm{MWh}$ of electrical power. The first phase is scheduled for 2011 and will produce 300,000 tons of pellets.

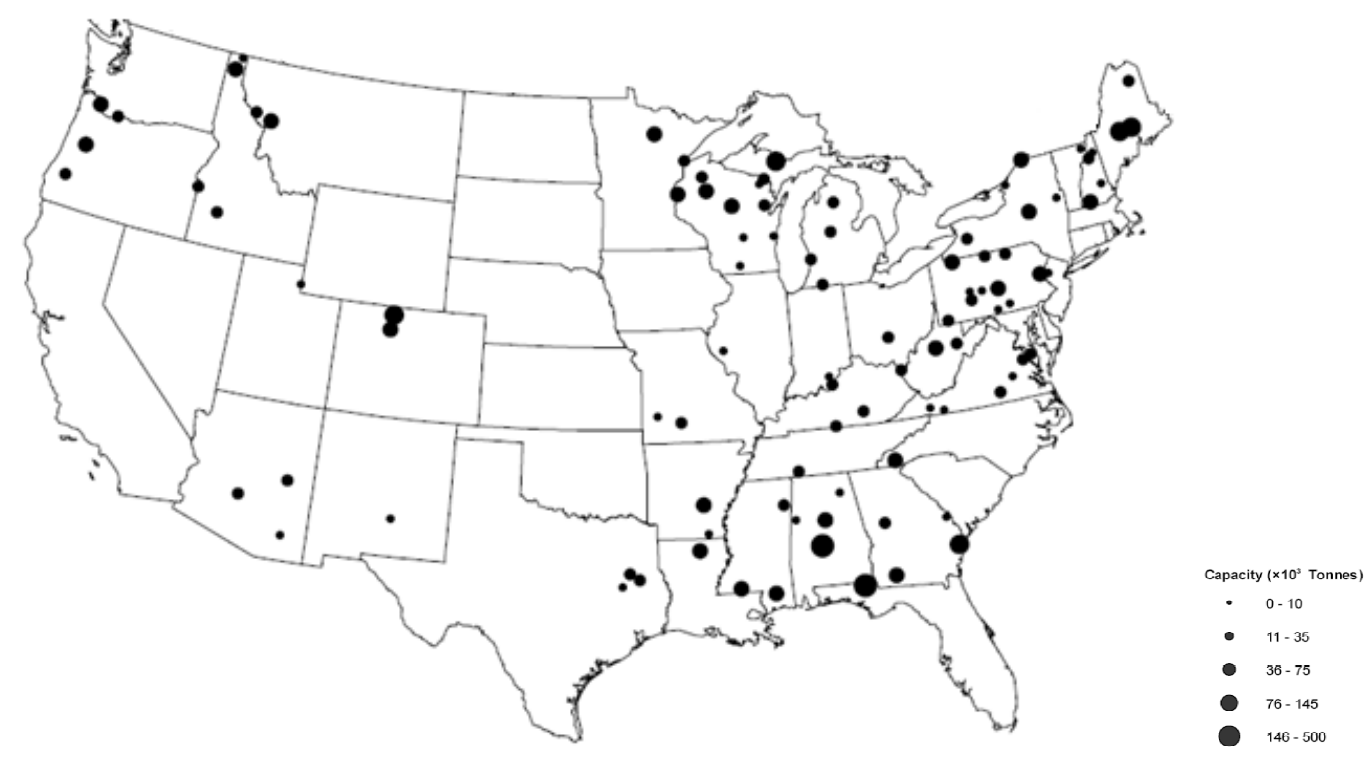

Figure 3: U.S. Wood Pellet Producers (Source: [9]).

\section{Consumption and Exports}

Renewable energy represents 7.7 quadrillion Btus of the nation's 94.5 quadrillion Btu total energy consumption. Wood and wood wastes generated in primary wood processing mills account for a third of the total industrial biomass energy consumption (see Figure 4). The U.S. biomass consumption profile 
has increased 8 percent from 2008 to 2009 and is forecasted to be the fastest-growing source of electricity through 2035 [11].

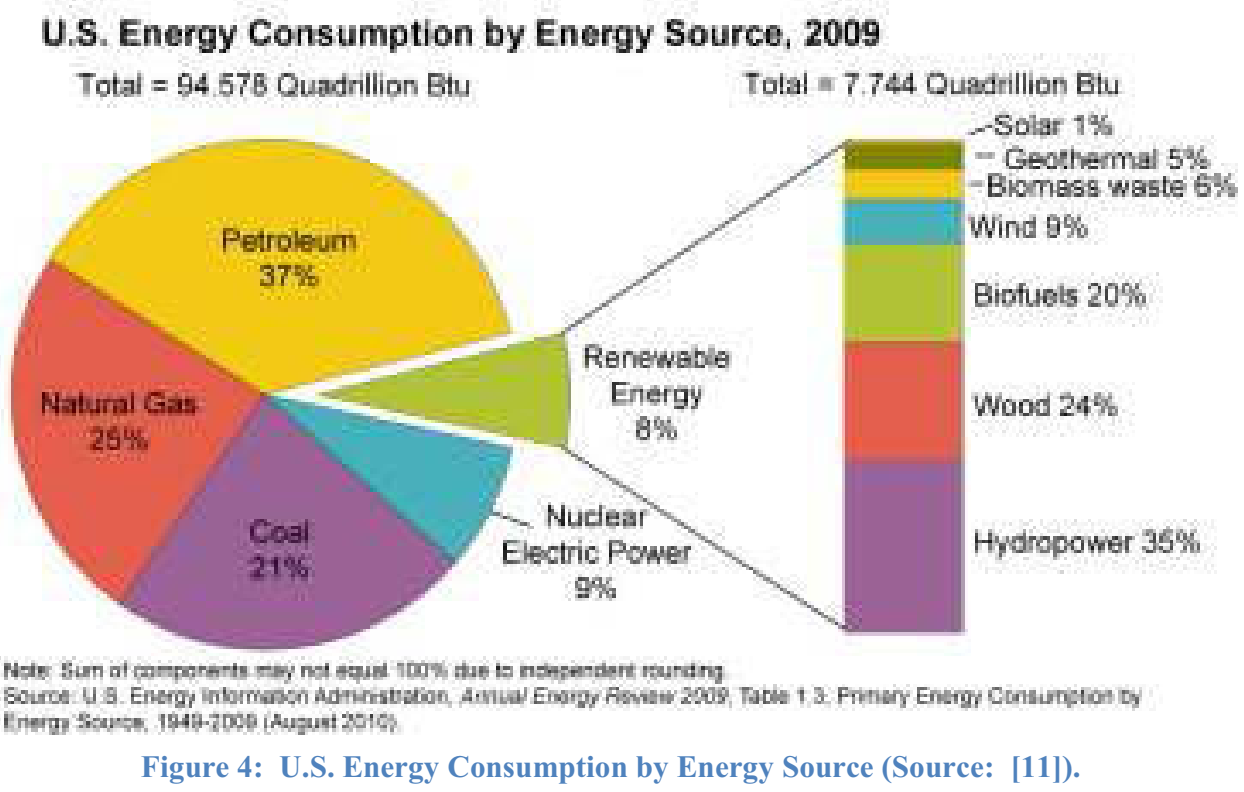

In 2008, over 80 percent of pellets produced in the US were used domestically; of the remaining, about 19 percent were exported to Europe and half a percent to Canada (see Figure 5). By contrast, most Canadian pellets are shipped overseas [9].

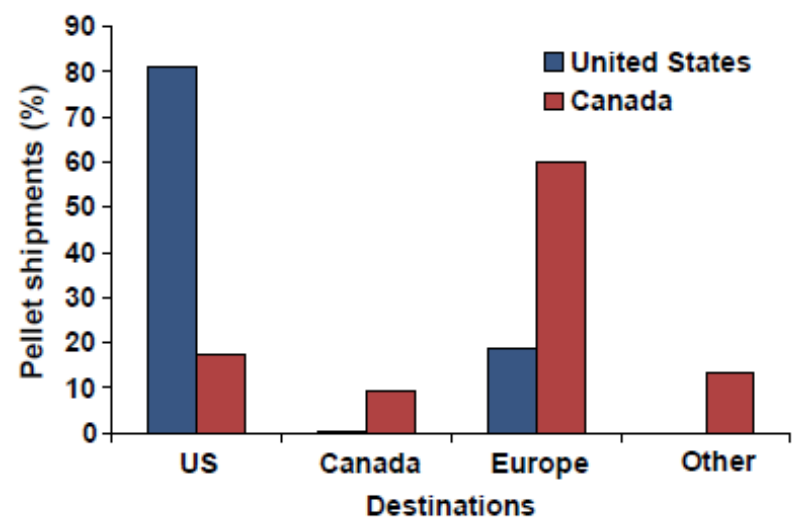

Figure 5: Destinations for Pellets Produced in U.S. and Canada (Source: [9]).

The demand for biomass pellets in Europe has been rapidly increasing in recent years. In 2005, the European Union experienced a 16 percent growth in electricity produced from biomass. This growth is expected to continue and that is attracting U.S. industries to expand their production of wood pellets explicitly for export to the EU. The demand in the European Union for wood pellets increased $7 \%$ in 2010, to 11 million tons [12]. North America has doubled its export volume to Europe over the past two years. In 2010, an approximately 1.6 million tons of pellets were shipped from the U.S. and Canada to the Netherlands, the UK, and Belgium [13], and exports are expected to continue to increase as the E.U. moves to obtain its mandates of $20 \%$ renewable energy by 2020 .

Growth in North America put pressure on any new pellet production capacity for the Western Canadian Producers; as a result any extra volumes in the U.S. are directed towards this market rather than towards 
Europe. More stringent carbon emissions regulations could increase co-firing efforts for coal plants in the U.S. and Europe, resulting in a substantial need for pellets.

\section{Prices}

Prices for pellets in the U.S. vary by season, region, and supply and demand in the same way other heating fuels do. In the U.S., pellets are sold by the bag (40 lb), by the ton (50 bags), and by the skid (60 bags). The selling price currently ranges from $\$ 219$ to $\$ 280$ per ton ( $\$ 4.60$ to $\$ 5.60$ per bag) and averages $\$ 250$ per ton $(\$ 5.20$ per bag).

Because bags of pellets stack and store easily, many prudent customers take advantage of lower off season prices and ensure their winter fuel supply by buying early. Selling price, of course, is only a part of the cost picture. The primary issue is the cost of energy, which is measured in dollars per million British thermal units. Pellets purchased at the average $\$ 150$ per ton and burned in a typical pellet stove cost about $\$ 14.00$ per million Btu, a figure that is less than the cost of electric heat (roughly $\$ 30$ per million Btu) and competitive with average energy costs of some other fuels. Natural gas prices, however, are currently lower. Prices for natural gas range between $\$ 4.50-\$ 5.50$ per million Btu, and are likely to remain low for the foreseeable future. This will continue to be the main impediment to large-scale adoption of biomass for home heating, except in areas where it is not available.

\section{Economic Drivers}

There are a number of instruments in use in the U.S. at either the federal or state level influencing biomass energy production or use.

\section{$\underline{\text { Federal Biomass Economic Drivers }}$}

At the federal level two programs were introduced in the early 1990s as part of the Energy Policy Act of 1992. The Renewable Energy Production Incentive (REPI) provides incentives for electrical generation from green energy generation facilities. Qualifying facilities are eligible for annual incentive payments of 1.5 cents per kWh (1993 dollars and indexed for inflation). The Renewable Energy Production Tax Credit allowed the same 1.5 cents per kWh (real 1993 currency) incentive to private facilities in the form of a tax credit available to facilities generating electricity from wind, closed-loop biomass, or poultry waste. This was initially a 10-year program, but was renewed in 2004 for another decade and the list of eligible energy sources has been expanded to include open-loop biomass, solar, municipal solid waste, geothermal, and small irrigation power.

Also at the federal level, and the foremost government driver pushing for renewable energy is the Energy Independence \& Security Act of 2007 (EISA). EISA was signed by the President on December 19, 2007 after being announced in the State of the Union address as the "Twenty in Ten" plan to boost biofuel production by setting a timeline and goals it has since been expanded through 2022. EISA included the Renewable Fuel Standard 2 (RFS-2), enforced by the U.S. Environmental Protection Agency, which mandates by law increasing the volume of biomass that must be used for renewable energy (See Table 3). RFS-2 mandates that by 202236 Billion gal/year biofuels must be produced in the U.S. to offset petroleum use. Of the 36 billion gal/year, 21 billion gal/year will come from advanced biofuel production. Of that 21 billion gal/year, 16 billion gal/year will come from cellulosic biofuels, and the remainder from Biomass based Diesel and other advanced biofules [2]. Advanced biofuels are essentially any biofuel other than corn starch ethanol, which also meet a 50 percent lifecycle Greenhouse Gas (GHG) threshold. 
Table 3: Biofuels Targets Mandated by EISA, Volume in Billion Gallons (Source: [2])

\begin{tabular}{|c|c|c|c|c|c|c|}
\hline \multirow[b]{2}{*}{ Year } & \multirow{2}{*}{$\begin{array}{c}\text { Total Volume } \\
\text { (Conventional } \\
\text { + Advanced) } \\
\end{array}$} & \multirow[b]{2}{*}{$\begin{array}{c}\text { Conventional } \\
\text { Biofuels }\end{array}$} & \multirow{2}{*}{$\begin{array}{c}\text { Advanced } \\
\text { Biofules } \\
\text { Total } \\
\end{array}$} & \multicolumn{3}{|c|}{ Advanced Biofuels by Type } \\
\hline & & & & $\begin{array}{c}\text { Cellulosic } \\
\text { Biofuels } \\
\end{array}$ & $\begin{array}{c}\text { Biomass-Based } \\
\text { Diesel a }^{\text {a }} \\
\end{array}$ & $\begin{array}{c}\text { Undifferentiated } \\
\text { Advanced Biofuels } \\
\end{array}$ \\
\hline 2006 & 4.00 & 4.00 & & & & \\
\hline 2007 & 4.70 & 4.70 & & & & \\
\hline 2008 & 9.00 & 9.00 & & & & \\
\hline 2009 & 11.10 & 10.50 & 0.60 & & 0.50 & 0.10 \\
\hline 2010 & 12.95 & 12.00 & 0.95 & 0.10 & 0.65 & 0.20 \\
\hline 2011 & 13.95 & 12.60 & 1.35 & 0.25 & 0.80 & 0.30 \\
\hline 2012 & 15.20 & 13.20 & 2.00 & 0.50 & 1.00 & 0.50 \\
\hline 2013 & 16.55 & 13.80 & 2.75 & 1.00 & $>1.000$ & 0.75 \\
\hline 2014 & 18.15 & 14.40 & 3.75 & 1.75 & $>1.000$ & 1.00 \\
\hline 2015 & 20.50 & 15.00 & 5.50 & 3.00 & $>1.000$ & 1.50 \\
\hline 2016 & 22.25 & 15.00 & 7.25 & 4.25 & $>1.000$ & 2.00 \\
\hline 2017 & 24.00 & 15.00 & 9.00 & 5.50 & $>1.000$ & 2.50 \\
\hline 2018 & 26.00 & 15.00 & 11.00 & 7.00 & $>1.000$ & 3.00 \\
\hline 2019 & 28.00 & 15.00 & 13.00 & 8.50 & $>1.000$ & 3.50 \\
\hline 2020 & 30.00 & 15.00 & 15.00 & 10.50 & $>1.000$ & 3.50 \\
\hline 2021 & 33.00 & 15.00 & 18.00 & 13.50 & $>1.000$ & 3.50 \\
\hline 2022 & 36 & 15 & 21 & 16 & $>1.000$ & 4 \\
\hline
\end{tabular}

a. EPA Administrator determines minimum use allocation for "biomass-based diesel" beginning in 2013.

\section{$\underline{\text { State Biomass Economic Drivers }}$}

Emission compliance strategies at the state level have also started to actively enforce Renewable Portfolio Standards (RPS). Each state has adopted its own, state-specific policy objectives with consideration to resources, expansion capabilities, and political considerations and varies widely among states. As of June 2008, 29 states as well as DC and Puerto Rico have established mandatory RPS and additionally, 7 states have renewable portfolio goals(see Figure 6). Legislation for a federal RPS has been introduced that may force the states without a current RPS to conform to a national standard. 


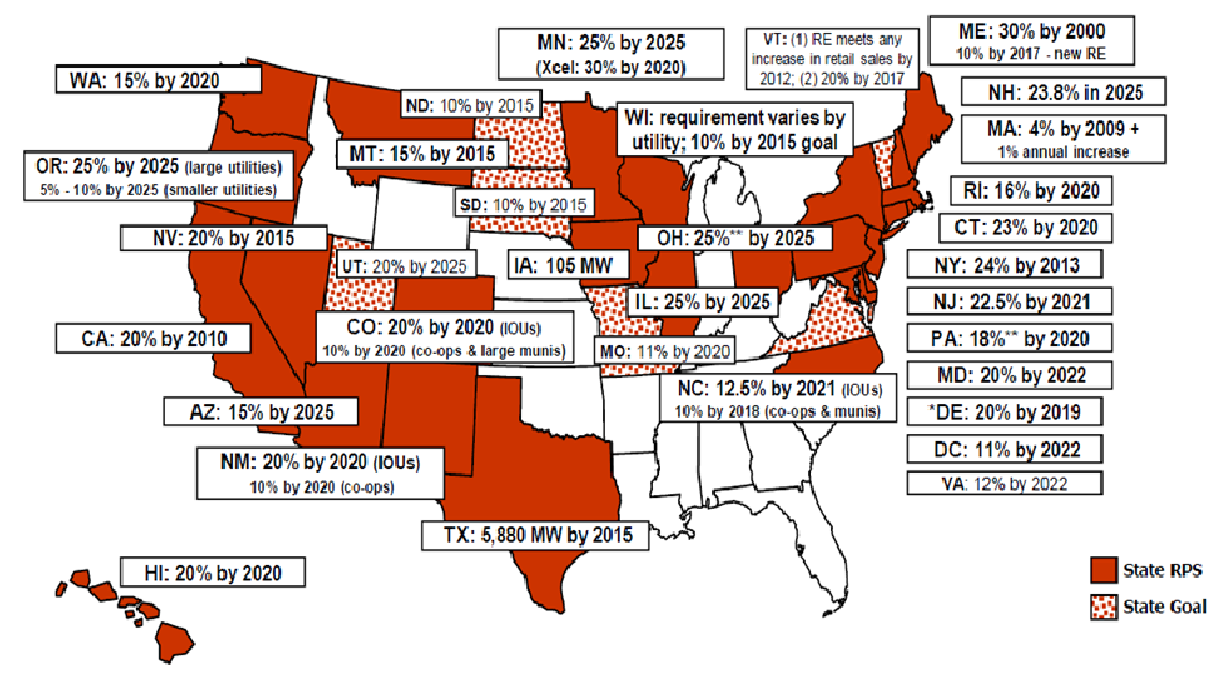

Figure 6: Renewables Portfolio Standards (Source: [14])

California has one of the most ambitions standards in the country and according to the executive order, they will produce a minimum of twenty percent of its own liquid biofuels by 2010 and forty percent by 2020. As of 2009, about 1 billion gallons of ethanol consumed in California per year as transportation fuel. Although California's liquid biofuels capacity is up, problems with corn-based fuels economic competitiveness against mid-west producers have left a shortfall in actual production. To fill this need, the Energy Commission has funded several pilot or full-scale demonstration projects for coproduction of ethanol and electricity from ligno-cellulosic biomass, and biomass-to-biofuel conversion continues to progress [15]. California is currently party to eight climate change and energy agreements with other states, nations and Canadian provinces. These agreements, the Governor's office states, are important because they expand markets for clean fuel cars and emissions credits across borders, allowing emission reductions at the lowest possible cost. California is working with other governments so that reporting, measuring, verifying and emissions markets have consistent protocols.

In addition to the RPS , a relatively common instrument for supporting environmentally friendly electricity generation is green pricing. These are voluntary programs where consumers pay a premium for electricity generated from environmentally friendly sources. These programs are available from over 500 utilities in 34 states, and over 50 percent of all U.S. consumers can purchase green power, with the mean level of premium being 2.6 cents per $\mathrm{kWh}$.

Other organizations have set targets that while not mandatory, have helped drive federal policy. One such group is the Biomass Research and Development Initiative's (BRDI) Technical Advisory Committee, which was established by the Biomass Research and Development Act of 2000. The BRDI Technical Advisory Committee has diverse representation from industry, academia, non-governmental organizations, and state governments. In its 2006 Vision Statement, the committee set a goal that by 2030 biofuels consumption would be equivalent to 5 billion gallons of gasoline, roughly 20 percent of the total market share, and biopower consumption would be 3.8 quadrillion Btu, or 7 percent of the market share. By 2030, the committee envisions bioproducts consumption to be 55.3 billion pounds [16].

Another organization, $25 \times 25$, whose steering committee is comprised of leaders from industry and state governments, has released policy recommendations and strategies aimed toward producing 25 percent of America's energy needs by 2025 by utilizing the country's agricultural and forest resources, while still 
meeting demands for food and feed [17]. They believe that this goal could increase the demand for cellulosic ethanol by 86 billion gallons a year and reduce the oil demand by 59 billion gallons.

State and federal agencies have set ambitious goals for renewable energy production. Ultimately, biomass will not be utilized for energy production if it is not economically viable. In order to decrease the cost of capture and utilization of biomass, it must be transportable in an economically viable form, and it must be commoditized. Pelleting increases bulk density and durability, and makes transport of biomass more efficient and economical. It also provides a uniform format which enables a standardized utilization of a variety of sources and types of biomass.

\section{Future Projections}

The biomass pellet industry is a nascent industry in the U.S., however, there has been a recent swell of interest in clean energy, including renewable biomass.

Individual states have set goals for biomass production, but the lack of federal mandates creates some uncertainty in the industry. Retiring coal will likely continue to be replaced with natural gas generation capacity, however, regulations will likely drive existing coal power plants to co-fire with biomass, which will create an increasing market for biomass pellets.

New technologies for torrefaction of biomass will enable power producers to transition from coal to biomass with little operational changes to the plants themselves. Torrefied pellets have a much higher energy density, lower moisture content, and are more stable for storage and transportation (more hydrophobic, immune to biological degradation, and are more physically durable). This will allow the use of torrefaction to create a stable commodity market for torrefied pellets [18]. The biggest challenge for pellet mills will be to match capacities needed for many power plants. Under current usage levels, a sudden coal to biomass conversion would likely overwhelm the current capabilities of the industry.

European exports may actually decrease in the future if the projected demand in the U.S. is realized due to biopower and domestic pellet consumption. As stated above, the DOE target is to replace $30 \%$ of transportation fuel use with biofuels, leading to a consumption of 530 million dry tons/year of biomass [4]. This may be a real concern for the European markets as they work to achieve the mandated increases in biomass energy production to $20 \%$ by 2020 [12].

As the U.S. develops a more established pellet plant capacity, opportunities in the power sector will continue to grow. Carbon dioxide mitigation policies that will increase fossil fuel costs will also help drive demand for biomass as an alternative fuel.

\section{References}

[1] Annual Energy Outlook 2011 Early Release Overview; Department of Energy, 2011, http://www.eia.gov/cneaf/alternate/page/renew_energy_consump/rea_prereport.html.

[2] Sustainable International Bioenergy Trade: Securing Supply and Demand, Report Number: INL/EXT-09-16132, 2009, http://www.inl.gov/technicalpublications/Documents/4336170, Accessed: 31 March, 2011.

[3] Bartis, Bibber, Alternative Fuels for Military Applications; 2011, RAND, National Defense Research Institute, http://www.rand.org/content/dam/rand/pubs/monographs/2011/RAND_MG969.pdf.

[4] Commodity-Scale Production of an Infrastructure-Compatible Bulk Solid from Herbaceous Lignocellulosic Biomass; Idaho National Laboratory, Report Number: INL/EXT-09-17527, 2009. 
[5] Perlack, Wright, Turhollow, Graham, Stokes, Erbach, Biomass as Feedstock for a Bioenergy and Bioproducts Industry: The Technical Feasibility of a Billion-Ton Annual Supply; Oak Ridge National Laboratory, Report Number: ORNL/TM-2005/66, 2005, http://feedstockreview.ornl.gov/pdf/billion_ton_vision.pdf.

[6] Liquid Transportation Fuels from Coal and Biomass: Technological Status, Costs, and Environmental Impacts: The National Academies Press; 2009.

[7] Biofuel Feedstock Logistics: Recommendations for Research and Commercialization; Feedstock Logistics Interagency Working Group of the Biomass Research and Development Board 2010, http://www.usbiomassboard.gov/pdfs/biomass_logistics_2011_web.pdf, Accessed: 30 March, 2011.

[8] Milbrandt, A Geographic Perspective on the Current Biomass Resource Availability in the United States National Renewable Energy Laboratory, Report Number: NREL/TP-560-39181, 2005, http://www.nrel.gov/docs/fy06osti/39181.pdf.

[9] Spelter, Troth, North America's Wood Pellet Sector; Forest Service Forest Products Laboratory, Report Number: FPL-RP-656, 2009.

[10] Green Circle Bioenergy Inc., http://www.greencirclebio.com/plant.php, Accessed: 29 March.

[11] How much of our electricity is generated from renewable sources?; U.S. Energy Information Administration, 2010, http://www.eia.gov/energy_in_brief/renewable energy.cfm.

[12] Crowe, EU's Renewable Goals Driving Wood Pellet Growth; 2011,

http://www.renewableenergyworld.com/rea/news/article/2011/03/eus-renewable-goals-driving-woodpellet-growth, Accessed: 12 April, 2011.

[13] North American Pellet Exports Reach 1.6 Million Tons; 2011, Fordaq, http://timber.fordaq.com/fordaq/news/woodpellets_woodchips_Canada_US_25842.htmlhttp://timber.ford aq.com/fordaq/news/woodpellets_woodchips_Canada_US_25842.html, Accessed: 30 March, 2011.

[14] www.desireusa.org, Accessed: 31 March, 2011.

[15] 2009 Progress to Plan Bioenergy Action Plan for California; California Energy Commission, Report Number: CEC-500-2010-007, 2009, http://www.energy.ca.gov/2010publications/CEC-500-2010007/CEC-500-2010-007.PDF.

[16] BR\&Di (Biomass R\&D Technical Advisory Committee) (2006) Vision for Bioenergy and Biobased Products in the United States, 2009, http://www.brdisolutions.com/Site\%20Docs/Final\%202006\%20Vision.pdf, Accessed: 30 June, 2009. [17] 25x25 Action Plan: Charting America's Energy Future; 25x25 National Steering Committee, 2007 , http://www.25x25.org/storage/25x25/documents/IP\%20Documents/Action_Plan/actionplan_64pg_11-1107.pdf, Accessed: 30 June, 2009.

[18] Kiel, Torrefaction for Biomass Upgrading into Commodity Fuels; 2007, Energy Research Center for the Netherlands, http://www.ieabcc.nl/meetings/task32_Berlin_ws_system_perspectives/03_Kiel.pdf. 